\title{
EVALUATION OF THE ANTICONVULSANT EFFECT OF AQUEOUS EXTRACT OF CENTELLA ASIATICA IN ALBINO MICE
}

\author{
DIPJYOTI DEKA ${ }^{1 *}$, PINAKI CHAKRAVARTY², AYAN PURKAYASTHA ${ }^{3}$
}

${ }^{1}$ Demonstrator, Department of Pharmacology, Silchar Medical College and Hospital, Silchar, Assam, India, ${ }^{2}$ Department of Pharmacology, Silchar Medical College and Hospital, Silchar, Assam, India, ${ }^{3}$ Demonstrator, Department of Pharmacology, Silchar Medical College and

Hospital, Silchar, Assam, India

Email: dipjyoti29@gmail.com

Received: 30 Sep 2016 Revised and Accepted: 07 Dec 2016

\section{ABSTRACT}

Objective: To evaluate the antiepileptic activity of aqueous extract of Centella asciatica in maximal electroshock (MES) and pentylenetetrazole (PTZ) induced convulsions.

Methods: The anticonvulsant activity of leaves of Centella asciatica $(200 \mathrm{mg} / \mathrm{kg}$ and $400 \mathrm{mg} / \mathrm{kg}$ ) in mice was assessed using MES and PTZ induced seizure models. Abolition of tonic hind limb extension (MES and PTZ) and increase in seizure latency (PTZ) when compared to control group, were taken as a measure of protection. Statistical analysis was done using one-way ANOVA followed by Tukey-Kramer multiple comparisons test. The test was considered to be significant at $\mathrm{p}<0.05$.

Results: The aqueous extract of Centella asiatica at a dose of $200 \mathrm{mg} / \mathrm{kg}$ has abolished tonic hind limb extension in 1 out of 6 animals in MES while there was no anticonvulsant action in PTZ convulsions. At a dose of $400 \mathrm{mg} / \mathrm{kg}$ body weight, the aqueous extract of Centella asiatica has shown a significant anticonvulsant effect against both MES and PTZ convulsions, where it has abolished tonic hind limb extension in 4 mice in MES method and in all 6 mices in PTZ method.

Conclusion: The aqueous extract of Centella asiatica showed efficacy in both MES and PTZ convulsions in mice at a dose of $400 \mathrm{mg} / \mathrm{kg}$. Since the clinical correlates of MES seizures are tonic-clonic convulsions and correlates of PTZ seizures are absence seizures, the aqueous extract of Centella asiatica is likely to be useful in the treatment of tonic-clonic and absence seizures.

Keywords: Anticonvulsant activity, Centella asiatica, Epilepsy, MES, PTZ model

(C) 2017 The Authors. Published by Innovare Academic Sciences Pvt Ltd. This is an open access article under the CC BY license (http://creativecommons.org/licenses/by/4. 0/) DOI: http://dx.doi.org/10.22159/ijpps.2017v9i2.15483

Epilepsy is one of the most common disarrays of the brain in the world. It is a disorder in which a person has frequent seizures due to a chronic, fundamental process [1]. This generally occurs because of unwarranted neuronal discharge in the brain [2]. Different areas of the brain may be involved. The characteristics of seizures differ and are dependent on where the commotion first begins in the brain and how far it extends [3]. Epilepsy has been described as Apasmara in the prehistoric Indian literature around 500-1000 BC [4].

Around 2.4 million people are diagnosed with epilepsy each year worldwide. $70 \%$ to $80 \%$ of people who have epilepsy can lead normal lives if they are properly treated [3]. In about $70 \%$ of cases, there is no understandable cause. This type of epilepsy often arises in childhood [5], with a high prevalence of about $0.8 \%$ below the age of $7 \mathrm{y}[6]$.

The hazard of epilepsy is maximum throughout the first year of life, and it diminishes during childhood and adolescence, but in the age range of 50-60 y the threat starts to increase again. According to the Rochester study approximately $50 \%$ of cases of epilepsy begin in childhood or adolescence [7], but in other epidemiological studies, $75-90 \%$ of cases of epilepsy have started before adulthood [8]. The overall collective occurrence of epilepsy has varied between 1-3\% in various studies and epilepsy seems to be more common in men than in women [9].

A significant number of drugs are accessible for the treatment of different types of seizures. The aim is to decrease the incidence and severity of seizures within a scaffold of a suitable level of side effects. A perfect anti-epileptic drug would restrain all seizures without causing any untoward consequence, but unluckily the drugs that are used currently not only fail to suppress seizure activity in some patients, they also produce recurrent adverse effects [10]. The copious side effect profile of the currently available antiepileptic drugs (AEDs) are of utmost distress for both the patients and their physicians.

Numerous efforts have been made previously to get hold of anticonvulsive drugs from plant sources and these attempts will continue until a suitable treatment option is obtainable [11]. Natural products from folk remedies have made significant contributions in the breakthrough innovation of modern drugs and can serve as an alternative option for the discovery of AEDs with novel structures and better tolerance [12].

Centella asiatica is a clonal, perennial herbaceous creeper belonging to the family Umbellifere (Apiceae). It is found all over India growing in damp places up to an height of $1800 \mathrm{~m}$. Commonly known as Mandukparni or Indian pennywort or Jalbrahmi, it has been used as a medicine in the Ayurvedic tradition of India for thousands of years and listed in the historic 'Sushruta Samhita', an ancient Indian medical text. Centella asiatica has been widely used in ayurveda for the treatment of epilepsy, various skin diseases, leprosy and malaria [13]. From the literature it is evident that Centella asiatica has been used in epilepsy and also that the plant is easily accessible in our place the present study was undertaken to study the anticonvulsant activity of aqueous extract of Centella asiatica in albino mice.

Male albino mice weighing 18-30 g were obtained from the animal house, Silchar Medical College and Hospital, Silchar, Assam and kept in the departmental polypropylene cages and acclimatised for $10 \mathrm{~d}$. All test animals are allowed free access to food and water ad libitum, both being withdrawn just prior to experimentation. Twelve hours dark-light cycle was maintained.

The chemicals used in the study were Pentylenetetrazole (from Sigma Aldrich), Valproic acid (from Sun pharmaceuticals), Phenytoin (from Abbott Pharmaceuticals). 
The design of the study is as follows:

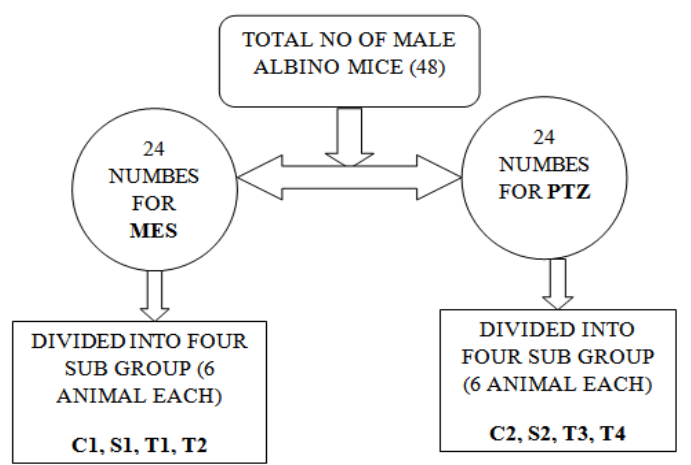

C1=Control group $(0.25 \mathrm{ml}$ of distilled water orally), $\mathbf{S 1}=$ Standard group $(50 \mathrm{mg} / \mathrm{kg}$ of phenytoin orally), T1= Test group (200 mg/kg of Centella asiatica orally), $\mathbf{T} 2=$ Test group ( $400 \mathrm{mg} / \mathrm{kg}$ of Centella asiatica orally), $\mathbf{C} 2=$ Control group $(0.25 \mathrm{ml}$ of distilled water orally) + Pentylenetetrazole ( 80 $\mathrm{mg} / \mathrm{kg}$ subcutaneously), $\mathbf{S} 2=$ Standard group ( $300 \mathrm{mg} / \mathrm{kg}$ of sodium valproate intraperitoneally)+Pentylenetetrazole (80 mg/kg subcutaneously), T3= Test group ( $200 \mathrm{mg} / \mathrm{kg}$ of Centella asiatica orally)+Pentylenetetrazole ( $80 \mathrm{mg} / \mathrm{kg}$ subcutaneously), T4= Test group (400 mg/kg of Centella asiatica orally)+Pentylenetetrazole ( $80 \mathrm{mg} / \mathrm{kg}$ subcutaneously).

The plant was collected from the vicinity of basic science building (SMCH). It was authenticated by Dr. Ashis Nath (Associate professor, Department of Botany, G. C. College, Silchar (No./GCC/ SIL/2014/198) It was cleaned with water and air dried in the shade. It was then powdered using a mixture grinder. $30 \mathrm{~g}$ of the powder was soaked in $200 \mathrm{ml}$ of cold water for $\sim 18 \mathrm{hr}$ at room temperature. The extract was first filtered through Whatman no. 1 filter paper to clarify and then through a 0.45 $\mu \mathrm{m}$ membrane filter [14]. The filtrate was evaporated to dryness at room temperature in a steady air current and the yield recorded as a percentage of the quantity of initial plant material used. The filtrate was evaporated to dryness at room temperature in a steady air current and the yield recorded as a percentage of the quantity of initial plant material used, and it was $33 \%$. The test solution of Centella asiatica was prepared by dissolving $2 \mathrm{~g}$ of an aqueous extract of Centella asiatica in $100 \mathrm{ml}$ of distilled water at room temperature. This solution had a concentration of $20 \mathrm{mg} / \mathrm{ml}$.

The mice were subjected to maximal electroshock (MES) convulsions using electro-convulsiometer (INCO, Ambala, India) by applying a current of $50 \mathrm{~mA}$ for 0.2 seconds via ear electrodes. The electrodes were moistened with saline solution before application. The resultant seizure passes through various phases: phase of tonic limb flexion, tonic limb extension, clonus, and post-ictal depression followed by recovery or death [15]. The mouse was considered as protected if the drug prevented the appearance of hind limb tonic extensor component of the seizure.
In the PTZ method, the mice received $80 \mathrm{mg} / \mathrm{kg}$ of PTZ subcutaneously [15]. Each mice was pretreated with drugs one hour before giving PTZ. Only those animals that exhibited a convulsive response in the form of clonus, tonic fore and hind limb flexion, tonic limb extension, post-ictal depression followed by recovery or death were used for the experiment. In this method abolition of tonic, hind limb extension phase was considered as protection conferred by the drug. The results of this study are expressed as mean \pm standard error of mean (mean \pm SE). Results are analysed by ANOVA and post hoc test was done by Tukey-Kramer multiple comparisons test. The significance is established when probability value ( $\mathrm{p}$-value) is less than 0.05 . $\mathrm{P}$ values are denoted as ${ }^{*} \mathrm{P}<0.05$ as significant, ${ }^{*} \mathrm{P}<0.01$ as highly significant and ${ }^{* * *} \mathrm{P}<0.001$ as very highly significant.

The Institutional Ethics Committee, Silchar Medical College, Silchar approved the protocol of the study (SMCH/IEC/SIL/2013/12-067).

The mean duration of tonic hind limb flexion, tonic hind limb extension, clonus, post-ictal depression and seizure latency (in case of PTZ method) are recorded for different test dose of Centella Asiatica (T1 $200 \mathrm{mg} / \mathrm{kg}$ and T2 $400 \mathrm{mg} / \mathrm{kg}$ for MES method and T3 $200 \mathrm{mg} / \mathrm{kg}$ and T4 $400 \mathrm{mg} / \mathrm{kg}$ for PTZ method) and findings are compared with the mean duration of abovementioned parameters recorded for the control group used for both PTZ and MES method.

Table 1: It shows comparison of mean duration (in seconds) with control group of different parameters in MES method

\begin{tabular}{lllll}
\hline Parameters duration in second & Group C1 & Group S1 & Group T1 & Group T2 \\
\hline Tonic hind limb flexon & $2.67 \pm 0.4216$ & $0^{* * *}$ & $0.75 \pm 0.359^{* *}$ & $0.33 \pm 0.333^{* * *}$ \\
Tonic hind limb extension & $12.33 \pm 0.6146$ & $0^{* * *}$ & $11.33 \pm 2.30 \mathrm{~ns}$ & $1.83 \pm 1.47^{* * *}$ \\
Clonus & $22.8 \pm 1.249$ & $11.2 \pm 0.7491^{* * *}$ & $11.5 \pm 2.46^{* * *}$ & $13.3 \pm 1.542^{* *}$ \\
Post ictal depression & $177 \pm 8.819$ & $0^{* * *}$ & $25 \pm 7.528^{* * *}$ & $12.5 \pm 6.021^{* * *}$ \\
\hline
\end{tabular}

Data are expressed as MEAN \pm SE. ${ }^{*} \mathrm{p}<0.05,{ }^{* *} \mathrm{p}<0.01,{ }^{* * *} \mathrm{p}<0.001$ (compared with control), $\mathrm{N}=6$, ns=not significant. One way ANOVA followed by Tukey-Kramer multiple comparisons test.

Table 2: Shows Comparison of mean duration (in seconds) with control group of different parameters in PTZ method

\begin{tabular}{lllll}
\hline Parameters duration in second & Group & Group & Group & Group \\
& C2 & S2 & T3 & T4 \\
\hline Seizure latency & $325.5 \pm 1.41$ & $0^{* * *}$ & $435.5 \pm 4.11^{* * *}$ & $0^{* * *}$ \\
Tonic hind limb flexion & $1.75 \pm 0.21$ & $0^{* * *}$ & $1.75 \pm 0.21^{\text {ns }}$ & $0^{* * *}$ \\
Tonic hind limb extension & $9.83 \pm 0.31$ & $0^{* * *}$ & $9.83 \pm 0.6^{\text {ns }}$ & $0^{* * *}$ \\
Clonus & $4.83 \pm 0.61$ & $0^{* * *}$ & $3.67 \pm 0.56^{\text {ns }}$ & $0^{* * *}$ \\
Post ictal dipression & $336 \pm 5.38$ & $0^{* * *}$ & $279.833 \pm 1.515^{* * *}$ & $0^{* * *}$ \\
\hline
\end{tabular}

Data are expressed as MEAN \pm SE. ${ }^{*} \mathrm{p}<0.05,{ }^{* *} \mathrm{p}<0.01,{ }^{* * *} \mathrm{p}<0.001$ (compared with control), $\mathrm{N}=6, \mathrm{~ns}=$ not significant. One way ANOVA followed by Tukey-Kramer Multiple Comparisons test. 
From table 1 it was evident that there was a decrease in the mean duration of tonic hind limb extension for both the test dose (T1 200 $\mathrm{mg} / \mathrm{kg}$ and T2 $400 \mathrm{mg} / \mathrm{kg}$ ) and it was highly significant compared with control for T2, it was statistically not significant for T1 with compared with control.

From table 2 it was observed that the decrease in mean duration of tonic hind limb extension was only statistically significant compared with control T4 (400 mg/kg of Centella asiatica).

In this study, for the screening of aqueous extract of Centella asiatica for anticonvulsant activity, two standard methods namely MES and PTZ methods had been used [16]. The parameters observed were the duration of tonic hind limb flexion, tonic hind limb extension, clonus, post-ictal depression and incidence of recovery and death. In both MES and PTZ methods, the mouse was considered protected if the drug abolished the tonic hind limb extension [14].

In MES method, comparison of mean duration of tonic hind limb extension of control group $(12.33 \pm 0.6146)$ with test groups indicate that there is a decrease in mean duration of tonic hindlimb extension in both groups $\mathrm{T} 1(11.33 \pm 2.305)$ and $\mathrm{T} 2(1.83 \pm 1.47)$ and it is statistically significant $(\mathrm{p}<0.001)$ only in group $\mathrm{T} 2$. In group $\mathrm{S} 1$, there is the complete abolition of tonic hind limb extension which is statistically significant $(\mathrm{p}<0.001)$. A comparison of test groups $\mathrm{T} 1$ $(11.33 \pm 2.305)$ and $\mathrm{T} 2(1.83 \pm 1.47)$ with group $\mathrm{S} 1(0 \pm 0.00)$, indicate that there is a significant difference between S1 and T1 $(\mathrm{p}<0.001)$, while no significant difference between S1 and T2. Since abolition of tonic hind limb extension is considered suggestive of protection against MES convulsions [15] and standard antiepileptic drugs such as phenytoin, valproate and lamotrigine, which are clinically proven to be competent in the treatment of generalized tonic-clonic and partial seizures, all abolish the hind limb tonic extension in the MES model [17, 18], the aqueous extract of Centella asiatica has anticonvulsant effect against MES convulsions at a dose of 400 $\mathrm{mg} / \mathrm{kg}$. This effect is comparable to that of phenytoin in this study.

In PTZ method, Comparison of mean duration of tonic hind limb extension of control group $(9.83 \pm 0.307)$ with test groups and standard indicates that there is no significant difference between group C2 (9.83 \pm 0.307$)$ and group T3 $(9.83 \pm 0.601)$, while in groups S2 and T4, there is abolition of tonic extensor phase which is statistically significant $(\mathrm{p}<0.001)$ compared to control group. Comparison of mean duration of tonic hind limb extension of standard group S2 $(0 \pm 0.00)$ with test groups T3 $(9.83 \pm 0.601)$ and T4 $(0 \pm 0.00)$ indicates that there is a significant difference between group S2 and group T3 $(\mathrm{p}<0.001)$, while no significant difference between group S2 and group T4.

The abolition of tonic hind limb extension has occurred in all mice in group T4 while in group T3 there is no abolition of tonic hind limb extension. Since the abolition of tonic hind limb extension is considered suggestive of protection against MES and PTZ convulsions $[14,15]$, the aqueous extract of Centella asiatica has anticonvulsant effect against PTZ convulsions at a dose of $400 \mathrm{mg} / \mathrm{kg}$. This effect is comparable to that of sodium valproate in this study.

From our study, we can conclude that aqueous extract of Centella asiatica has shown efficacy in both MES and PTZ convulsions in mice at a dose of $400 \mathrm{mg} / \mathrm{kg}$. Further studies are required to estimate the exact mechanisms, active principles and safety of the plant as a medicinal remedy for epilepsy.

We would like to thank Dr. Dolly Roy, Associate Professor of the department of Pharmacology, Silchar Medical College and Hospital for her valuable suggestions during our study. We also thank Dr. Ashis Nath, Associate professor, Department of Botany, G. C. College,
Silchar for his help in taxonomical identification. Also, we would like to thank ADRs monitoring centre, Pharmacovigilance Programme of India (PvPI) under Indian Pharmacopoeia Commission (IPC) for their support during the research.

\section{CONFLICT OF INTERESTS}

\section{Declared none}

\section{REFERENCES}

1. Gohain K, Kaushik S. Study of the anticonvulsant activity of ethanolic extract of seeds of Benincasa hispida linn. in albino rats. Asian J Pharm Clin Res 2014;7 Suppl 2:128-30.

2. Ladda PL. Screening of Ricinus communis linn. leaves for anticonvulsant and analgesic activity. Asian J Pharm Clin Res 2014;7:110-4

3. Epilepsy. (Internet); 2012. Available from: http:// medicaldictionary.thefreedictionary.com/Seizure+disorders.

[Last Accessed on 15 Jul 2015]

4. Jain $\mathrm{S}$. The need to launch a global campaign against epilepsy in South East Asia. Neurol Asia 2004;9:74-5.

5. Mitchell S, Taylor L. Diving and epilepsy. (Internet). Available from: www.nzunderwater.org.nz/pdf/NZUA-DivingEpilepsy. pdf. [Last accessed on 25 Dec 2014]

6. Cohen L. Epilepsy as a social problem. Br Med J 1958;2:672-5.

7. Hauser WA, Annegers JF, Kurland LT. The incidence of epilepsy and unprovoked seizures in Rochester. Minnesota: 1935-1984. Epilepsia 1993;34:453-68.

8. Sillanpaa M. Epilepsian epidemiologia. In: Larsen TA and Iivanainen (eds) Epilepsia. Finland: Otava, Keuruu; 1994. p. 42-7.

9. Hauser WA. Incidence and prevalence. In: Engel JJ and Pedley TA. (eds). Epilepsy: a comprehensive textbook. Philadelphia: Lippincott-Raven Publishers; 1997. p. 47-58.

10. Vyawahare NS, Khandelwal AR, Batra VR, Andnikam AP. Herbal anticonvulsants. J Herb Med Toxicol 2007;1:9-14.

11. Sonavane GS, Sarveiya VP, Kasture VS, Kasture SB. The anxiogenic activity of Myristica fragrance seeds. Pharmacol Biochem Behav 2002;71:247-52.

12. Raza M, Shaheen F, Choudhary MI, Rahman AU, Sombati S, Suria A, et al. Anticonvulsant effect of FS-1 subfraction isolated from roots of Delphinim Denudatum on hippocampal pyramidal neurons. Phytother Res 2003;17:38-43.

13. Nadkarni AK. Hydrocotyla asiatica Linn. In: Dr. KM Nadkarni's. Indian Materia Medica. Vol. 1. 3rd edition. Bombay, Popular Book Depot; 1954. p. 663-4.

14. Uppala PK, Krishna BM. Experimental evaluation of anticonvulsant activity of Hydrocotyle asiatica linn (Centella asiatica) in Albino mice. Pharm Biotika 2014;1:59-73.

15. Mittal R. "Antiepileptic.” In: Gupta SK. Drug screening methods. $1^{\text {st }}$ edition. New Delhi, Jaypee brother's medical publishers; 2004. p. 84-103.

16. Toman JEP, Everett GM. “Anticonvulsants.” In: Laurence DR, Bacharach AL. Evaluation of drug activities: Pharmacometrics. Vol. 1. Academic Press; 1964. p. 287-99.

17. Kupferberg HJ. Antiepileptic drug development program: a cooperative effort of government and industry. Epilepsia 1989;30 Suppl 1:51-6.

18. McDonald RL, Kelly KM. Antiepileptic drugs: Mechanisms of action. Epilepsia 1993;34:1-8.

\section{How to cite this article}

- Dipjyoti Deka, Pinaki Chakravarty, Ayan Purkayastha. Evaluation of the anticonvulsant effect of aqueous extract of Centella asiatica in albino mice. Int J Pharm Pharm Sci 2017;9(2):312-314. 